\title{
Perbandingan Metode Peramalan Jumlah Produksi Palm Kernel Oil (PKO) Menggunakan Metode Double Moving Average, Double Exponential Smothing dan Box Jenkins
}

\author{
Ika Meiza Maharani ${ }^{* 1}$, Achmad Fauzan*2
}

\begin{abstract}
One of Indonesia's significant results is oil palm. The reality of this plantation is not only owned by the government (BUMN) but also the private sector. Every period, the company does forecasting in terms of production, especially for the next period. Among them is to set production targets, company operations, and financial planning. Based on this, a study was conducted with the aim to predict the amount of palm kernel oil (PKO) production at PT. Mitra Mendawai Sejati for the next six (6) months. The method used is Double Moving Average, Double Exponential Smoothing and Box Jenkins. While the data used is historical data from the amount of palm kernel oil production for five (5) years obtained from the company. Based on the results of the study, received the forecast value of the Suayap output in 2019 with the best method, namely the Double Exponential Smoothing method. Based on the forecast we got in January at $949181.5 \mathrm{Kg}$, February at $963505.8 \mathrm{Kg}$, March at $977830.1 \mathrm{Kg}$, April at $992154.4 \mathrm{Kg}$, May at $1006478.6 \mathrm{Kg}$ and June $1020802.9 \mathrm{Kg}$ with MSE value of 47031163817, and RMSE of 216866.7 and parameter values (optimum weighting) for $\alpha=0.616667$ and $\beta=0.1548939$.
\end{abstract}

Keywords: Double Moving Average, Double Exponential Smoothing, Box Jenkins, Palm Kernel Oil.

\begin{abstract}
Abstrak
Salah satu hasil negara Indonesia yang cukup signifikan adalah kelapa sawit. Realitasnya perkebunan ini tidak hanya dimiliki oleh pemerintah (BUMN), namun juga pihak swasta. Setiap periodenya, perusahaan ini melakukan peramalan dalam hal produksi khususnya untuk periode berikutnya. Diantaranya adalah untuk menetapkan target produksi, operasional perusahaan maupun perencanaan keuangan. Berdasarkan hal tersebut, dilakukan penelitian dengan tujuan untuk meramalkan jumlah produksi palm kernel oil (PKO) kebun Suayap PT. Mitra Mendawai Sejati untuk 6 bulan ke depan. Digunakan metode Double adalah Double Moving Average, Double Exponential Smothing dan Box Jenkins. Sedangkan data yang digunakan merupakan data historis dari jumlah produksi palm kernel oil selama 5 (lima) tahun yang
\end{abstract}

\footnotetext{
*Universitas Islam Indonesia

${ }^{1} 16611053 @$ students.uii.ac.id, ${ }^{2}$ achmadfauzan@uii.ac.id
} 


\section{Ika Meiza Maharani ${ }^{1}$, Achmad Fauzan}

didapatkan dari perusahaan. Berdasarkan hasil penelitian, diperoleh nilai ramalan produksi kebun Suayap tahun 2019 dengan metode terbaik yaitu metode Double Exponential Smothing pada bulan Januari sebesar $949181.5 \mathrm{Kg}$, Februari sebesar 963505.8 Kg, Maret sebesar 977830.1 Kg, April sebesar 992154.4 Kg, Mei sebesar $1006478.6 \mathrm{Kg}$ dan Juni sebesar $1020802.9 \mathrm{Kg}$ dengan nilai MSE sebesar 47031163817, dan RMSE sebesar 216866.7 serta nilai parameter (pembobotan optimum) untuk $\alpha=0.616667$ dan $\beta=0.1548939$.

Kata kunci: Double Moving Average, Double Exponential Smoothing, Box Jenkins, Palm Kernel Oil.

\section{Pendahuluan}

Kekayaan sumberdaya alam dan keanekaragaman hayatinya merupaan salah salah yang dimiliki negara Indonesia. Indonesia merupakan negara dengan curah hujan dan struktur tanah yang bagus sehingga cocok untuk perkebunan, seperti perkebunan kelapa sawit. Oleh sebab itu negara Indonesia dijadikan sebagai produsen perkebunan kelapa sawit dunia.

Kelapa sawit sendiri mempunyai banyak manfaat yaitu sebagai bahan baku untuk industri minyak goreng dan sebagai bahan baku industri oleochemical yang cukup luas. Kelapa sawit juga digunakan untuk memenuhi kebutuhan konsumsi ekspor dan impor [1]

Perusahaan sawit di Indonesia sangat banyak, baik pemilik perusahaan swasta maupun pemerintahan, salah satunya yaitu perusahaan PT Sawit Sumbermas Sarana Tbk yang ada di Pangkalan Bun, Kalimantan Tengah.

PT. Sawit Sumbermas Sarana Tbk. (SSMS) memiliki 19 perkebunan kelapa sawit, 6 pabrik kelapa dan 1 pabrik inti sawit. PT. SSMS bercita-cita menjadi perusahaan perkebunan kelas dunia dengan misi mewujudkan potensi minyak kelapa sawit. Banyak produksi yang dapat di hasilkan dari kelapa sawit tersebut, salah satunya yaitu Palm Kernel Oil (PKO) atau biasa kita sebut dengan inti sawit.

Sebagai perusahaan produksi kelapa sawit yang memiliki cita-cita untuk menajadikan perkebunan kelapa sawit kelas dunia salah satunya perusahaan harus mengoptimalkan kegiatan produksi dimana khususnya untuk produksi PKO itu sendiri, guna untuk mencukupi kebutuhan konsumen setiap waktunya, maka oleh sebab itu peneliti akan memprediksikan produksi PKO dengan menggunakan beberapa model, disini diharapkan agar perusahaan dapat mengantisipasi setiap kenaikan dan penurunan dari produksi PKO itu sendiri sehingga jika perusahaan ingin memproduksi PKO kembali dapat di persiapkan sesuai dengan kebutuhan untuk periode selanjutnya.

Data jumlah produksi PKO merupakan data timeseries. Dimana data timeseries adalah data yang diamati berdasarkan urutan waktu yang digunakan untuk membuat peramalan selanjutnya. Tahap selanjutnya untuk menetukan metode peramalan pada data Time Series kita harus mengetahui pola data sehingga sesuai dengan metode yang akan kita gunakan. Pola data timeseries dibedakan menjadi empat jenis, yaitu pola siklis, trend, musiman dan horizontal. Pola 


\section{Ika Meiza Maharani ${ }^{1}$, Achmad Fauzan}

data musiman sangat dipengaruhi faktor musiman. Pola data siklis dipengaruhi oleh fluktuasi ekonomi jangka panjang. Pola data Trend dipengaruhi kenaikan atau penurunan periode jangka panjang atau stationer. Sedangkan Pola data horizontal ketika data berfluktuasi di sekitaran rerata[2].

Pada studi kasus kali ini menggunakan data yang dipengaruhi oleh pola Trend sehingga disini peneliti akan membandingkan untuk beberapa metode yaitu metode Double Moving Average (DMA), Double Exponential Smothing (DES), dan Box Jankins untuk mendapatkan metode terbaik di antara ketiganya. Tujuan dari penelitian ini adalah sebagai berikut :

1. Mendapatkan gambaran secara umum jumlah produksi PKO di PT. Mitra Mendawai SejatiPKS Suayap pada Tahun 2014-2018

2. Mendapatkan parameter terbaik dari perbandingan metode DMA, DES, dan Box Jenkins yang digunakan, untuk membandingkan jumlah data asli dari produksi PKO di PT. Mitra Mendawai Sejati-PKS Suayap pada Tahun 2018.

3. Mendapatkan peramalan jumlah produksi PKO di PT. Mitra Mendawai Sejati-PKS Suayap pada Tahun 2019

\section{Metode Penelitian}

\section{Tempat dan Waktu Penelitian}

Penelitian dilakukan di Kantor pusat PT. Sawit Sumbermas Sarana Tbk., Kalimantan Tengah. Penelitian dilakukan tanggal 16 Januari 2018 sampai dengan 16 Februari 2018.

\section{Data dan Sumber data}

Data yang peneliti peroleh dalam penelitian ini merupakan data sekunder, dimana data diambil dari buku Laporan Tahunan PT Sawit Sumbermas Sarana Tbk., yaitu data Jumlah Produksi PKO PT. Mitra Mendawai Sejati - PKS Suayap pada tahun 2014-2018

\section{Metode Penelitian}

Sebagai awalan, dalam menggambarkan keadaan PT SSMS yaitu analisis satatistik deskriptif dan metode forecasting untuk memperoleh nilai hasil peramalan jumlah Produksi PKO PT. Mitra Mendawai Sejati - PKS Suayap periode Januari sampai dengan Desember 2019. Berdasarkan pola data dan karakteristik data yang dimiliki metode peramalan yang digunakan yaitu metode DMA, DES, dan Box Jenkins menggunakan software R. Berikut ini langkah-langkah yang dilakukan, yaitu :

1. Memasukan data yang telah dikumpulkan kedalam software untuk dianalisis.

2. Melakukan identifikasi model.

3. Memilih model yaitu DMA, DES, dan Box Jenkins

4. Untuk model DMA, peneliti akan menentukan waktu periodenya, lalu menentukan jumlah periode dan membagi hasil perhitungan periode dengan data awal.

5. Kemudian untuk metode DES, pertama peneliti menentukan nilai alpha dan beta, lalu mencari nilai prediksi. 


\section{Ika Meiza Maharani ${ }^{1}$, Achmad Fauzan}

6. Lalu untuk metode Box Jankins, peneliti melakukan preprocessing data, lalu estimasi model dan uji diagnostic, jika uji diagnostik terpenuhi maka lanjut peramalan, jika tidak maka kembali ke preprocessing data.

7. Melakukan uji peramalan untuk masing-masing metode.

8. Menentukan nilai error

\section{Flowchart}

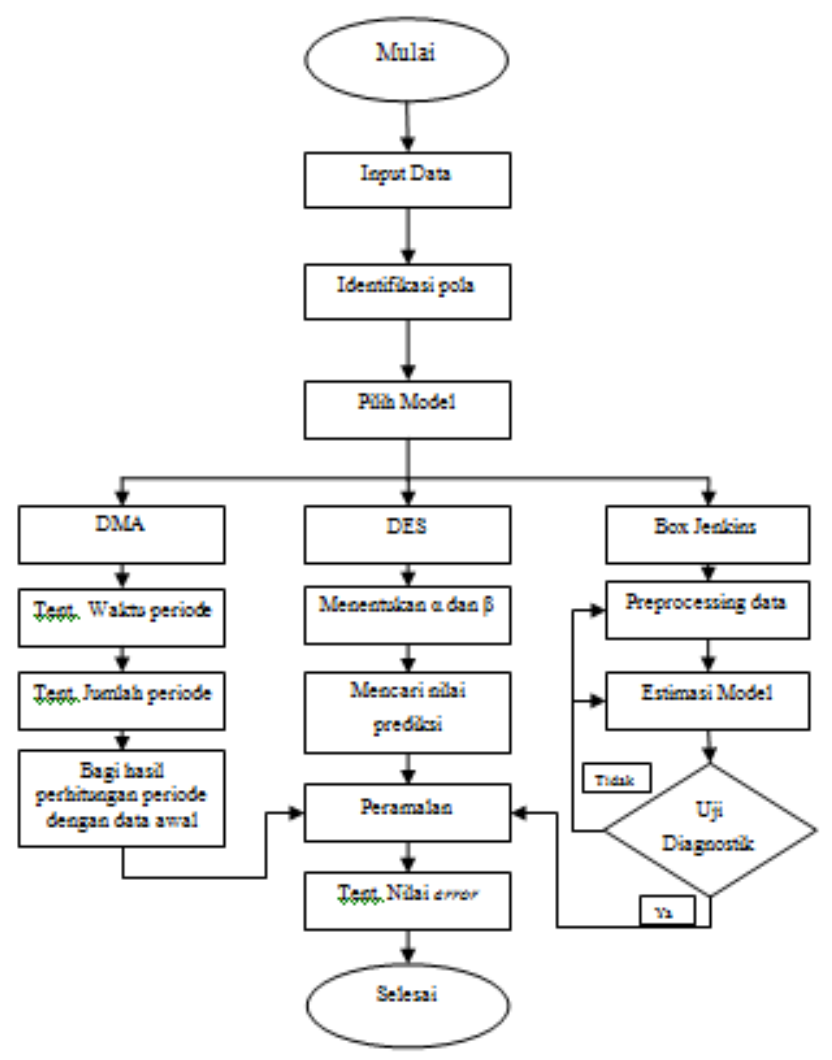

Gambar 1. Flowchart langkah-langkah pengerjaan

\section{Hasil dan Pembahasan}

\section{Statistika Deskriptif}

Statistika deskriptif merupakan bagian statistika terkait pengumpulan data, penyajian, penentuan nilai-nilai statistika, pembuatan diagram atau gambar mengenai sesuatu hal [3], dalam penelitian ini disajikan pada Gambar 2. 


\section{Ika Meiza Maharani ${ }^{1}$, Achmad Fauzan}

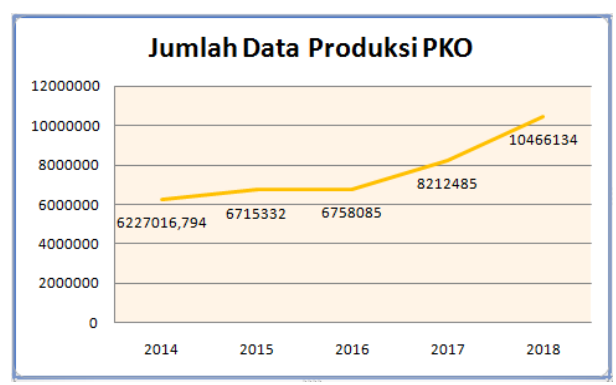

Gambar 2. Grafik jumlah produksi PKO pada tahun 2014-2018.

Berdasarkan grafik diatas terlihat bahwa Produksi Palm Kernel Oil (PKO) dari tahun 2014 sampai tahun2018 tidak stabil. Dapat dilihat pada tahun pertama yaitu tahun 2014 Produksi PKO PT. Mitra Mendawai Sejati - PKS Suayap mencapai 6227016.794 kg, kemudian mengalami peningkatan yang relatif stabil, namun pada tahun 2016 sedikit mengalami penurun hingga pada tahun 2018 mencapai $10466134 \mathrm{~kg}$.

Tabel 1. Rata-rata dan Growth jumlah produksi Rata-rata dan Growth jumlah produksi PKO pada

\begin{tabular}{cccc}
\multicolumn{4}{c}{ tahun 2014-2018 } \\
\hline Tahun & \multicolumn{3}{c}{ Produksi PKO } \\
\cline { 2 - 4 } & Rata-rata & Jumlah & Growth \\
\hline 2014 & 518918,0661 & 6227016,794 \\
2015 & 559611 & 6715332 & $7,84 \%$ \\
2016 & 563173,75 & 6758085 & $0,64 \%$ \\
2017 & 684373,75 & 8212485 & $21,52 \%$ \\
2018 & 872177,8333 & 10466134 & $27,44 \%$ \\
\hline
\end{tabular}

Berdasarkan Tabel 1. dapat diketahui jumlah produksi PKO, rata-rata Produksi PKO dan Growth jumlah produksi PKO di PT. Mitra Mendawai Sejati-PKS Suayap tahun 2014 sampai dengan tahun 2018.

Dari Tabel 1 juga dapat diketahui jumlah Produksi PKO tertinggi yaitu pada tahun 2018 dengan jumlah Produksi PKO sebesar $10466134 \mathrm{~kg}$ dengan rata-rata produksi PKO setiap bulannya adalah 872177.8333 dan Growth sebesar 27448 \%. Jumlah Produksi PKO terendah yaitu pada awal tahun atau pada tahun 2014 dengan jumlah Produksi PKO sebesar 6227016.794 kg dengan rata-rata produksi PKO setiap bulannya adalah 518918.0661. Growth disini merupakan pertumbuhan produksi yang nantinya akan digunakan sebagai acuan keberhasilan dari waktu yang sudah berlalu dan dijadikan sebagai prediksi pertumbuhan untuk masa mendatang.

\section{Identifikasi Pola}




\section{Ika Meiza Maharani ${ }^{1}$, Achmad Fauzan}

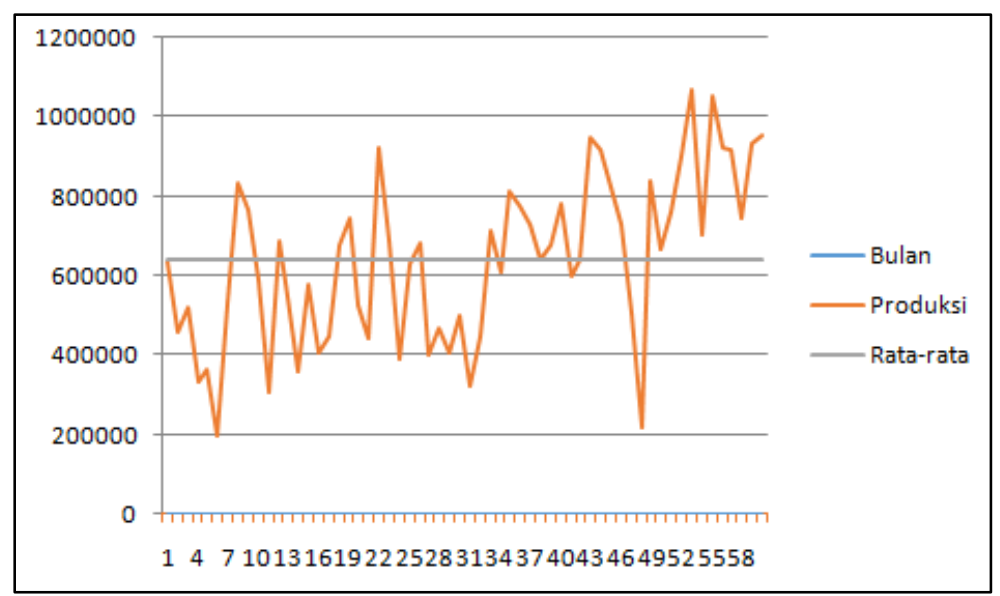

Gambar 3. Identifikasi Pola.

Berdasarkan grafik gambar 3 dapat dilihat bahwa produksi PKO memiliki 60 data periode yaitu (periode Januari 2014 hingga pada Desember 2018) dan dapat kita lihat juga bahwa data cendrung selalu meningkat pada setiap tahunnya maka dapat dikatakan bahwa data merupakan data trend. Untuk Volume produksi PKO yang tertinggi yaitu pada data ke 53 atau sebesar $1069203 \mathrm{~kg}$, yaitu pada bulan Mei 2018. Selanjutnya untuk volume produksi PKO terendah terjadi pada data ke 6 atau sebesar $195566 \mathrm{~kg}$, yang terdapat pada bulan Juni 2014.

\section{Analisis Metode Double Moving Average}

Pada teknik DES dilakukan penghitungan rata-rata bergerak sebanyak dua (2) kali dan dilanjutkan ke tahap peramalan berdasarkan persamaan tertentu. Double moving average dapat digunakan ketika data aktual mempunyai pola tren. Pada metode ini orde yang digunakan tidak harus sama, misal 3x3, maksudnya dari data awal dilakukan moving average dengan orde 3, kemudian hasil dari MA(3) dilakukan moving average dengan orde 3 juga. [4]

Untuk orde yang digunakan dalam penelitian ini adalah orde $3 \times 3,4 \times 6$ dan $5 \times 7$. Orde ini diambil berdasarkan perkalian angka terkecil.

Tabel 2. Perbandingan nilai error/MSE dari DMA

\begin{tabular}{cc}
\hline $\begin{array}{c}\text { Moving Average } \\
\text { Orde }\end{array}$ & Nilai MSE \\
\hline $3 \times 3$ & 66630720936 \\
$4 \times 6$ & 64189828802 \\
$5 \times 7$ & 63446194592 \\
\hline
\end{tabular}

Berdasarkan hasil perhitungan metode moving average diatas dapat dilihat bahwa nilai Mean Squared Error (MSE) terkecil atau berada pada orde 5x7 yaitu dengan nilai MSE sebesar 63446194592, Mean Squared Error (MSE) sendiri merupakan metode untuk mengukur tingkat keakuratan suatu model peramalan, yang menunjukkan penyimpangan yang terjadi untuk metode Double Moving Average sebesar 63446194592. Selanjutnya dengan menggunkan orde $5 \times 7$ akan mendapatkan nilai peramalan untuk bulan Juli, hingga Desember pada Tahun 2018. 


\section{Ika Meiza Maharani ${ }^{1}$, Achmad Fauzan}

\section{Analisis Metode Double Exponential Smothing}

Metode DES digunakan jika data berbentuk trend. Maka untuk penelitian ini terlihat bahwa peramalan cendrung dengan arah trend dapat dilihat dari trend terakhir terbentuk dari produksi PKO.

Dalam metode DES terdapat koefisien pemulusan yaitu koefisien alfa $(\alpha)$ dan betta $(\beta)$.

Berikut adalah perbandingan nilai error dengan $\alpha(0.3) \beta(0.5), \alpha(0.4) \beta(0.6), \alpha(0.7)$ $\beta(0.2)$.

Tabel 3. Perbandingan nilai error/MSE dari DES

\begin{tabular}{ccc}
\hline \multicolumn{2}{c}{ Double Exponential Smothing } & Nilai \\
A & $\beta$ & MSE \\
\hline 0.3 & 0.5 & 60827116289 \\
0.4 & 0.6 & 58900441243 \\
0.7 & 0.2 & 51062893287 \\
\hline
\end{tabular}

Berdasarkan hasil perbandingan nilai Mean Squared Error (MSE) untuk data produksi PKO pada PT. Mitra Mendawai Sejati - PKS Suayap menunjukkan bahwa nilai kesalahan (error) terkecil untuk metode Double Exponential Smothing (DES) yaitu terdapat pada nilai $\alpha$ sebesar 0,7 dan nilai $\beta$ sebesar 0,2 dengan nilai MSE sebesar 3216539234 atau menunjukkan bahwa nilai penyimpangan dalam metode tersebut sebesar 3216539234 .

\section{Analisis Metode Box Jenkins}

Metode Box-Jenkins merupakan model terbaik untuk data yang stasioner. Jika data belum stationer maka data harus di stasionerkan terlebih dahulu sebelum di lakukan peramalan dengan proses (differencing). [5]

data : PKO

\section{Augmented Dickey-Fuller Test}

Dickey-Fuller $=-3.767$, Lag order $=3$, -value $=0.02741$

Alternative hypothesis : stationary

Gambar 2. Uji ADF Test

Berdasarkan output diatas di dapatkan nilai $p$-value sebesar 0.02741 atau < aplha (0.05), yang artinya data bersifat stasioneritas.

Selanjutnya peneliti akan melihat pola ACF dan PACF data aktual produksi PKO untuk mendapatkan model. 


\section{Ika Meiza Maharani ${ }^{1}$, Achmad Fauzan}
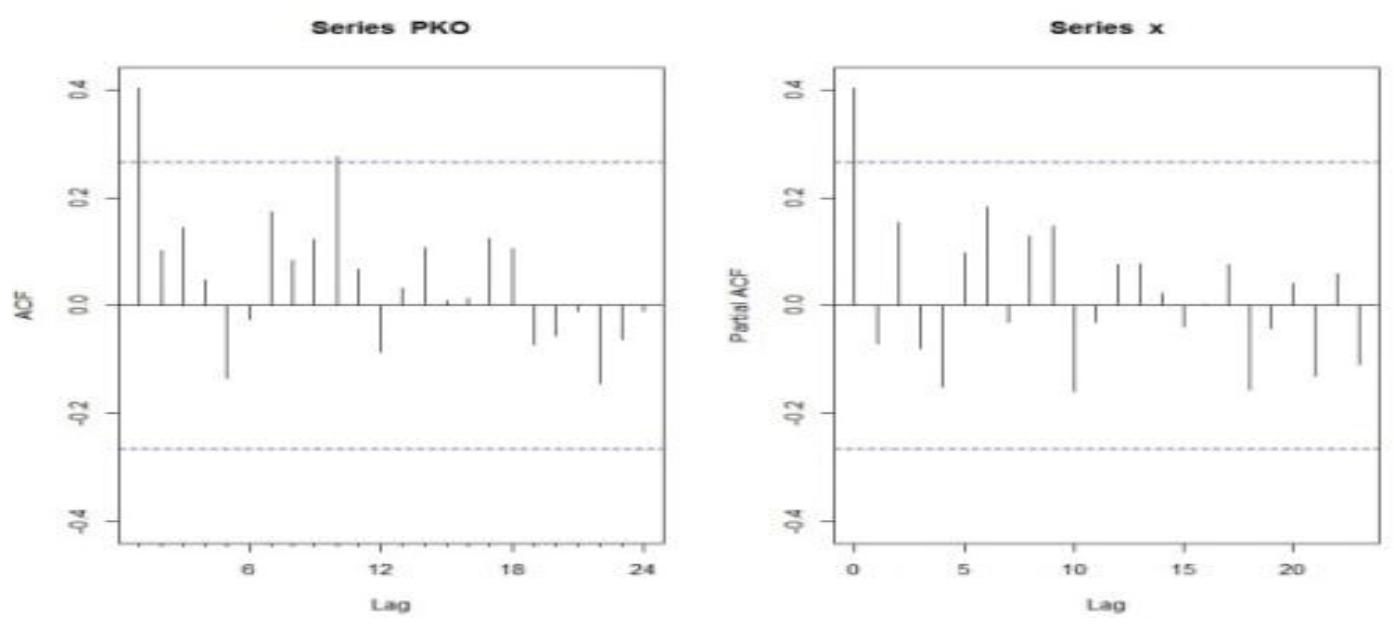

Gambar 3. Plot ACF dan PACF.

Dari plot tersebut dapat diperhatikan bahwa batang ACF yang keluar terdapat satu batang yang menunjukkan order MA yaitu $q=1$. Sedangkan batang PACF yang keluar ada satu yang menunjukkan order AR yaitu $p=1$. Dengan sebelumnya tidak dilakukan diferensi order $(d=0)$, diperoleh model ARIMA $(1,0,1)$.

Lalu selanjutnya peneliti akan mengestimasi model, berikut ringkasan yang peneliti buat.

Tabel 4. Estimasi Model

\begin{tabular}{lll}
\hline Model & $p$-value & AIC \\
\hline$(1,0,1)$ & Tidak signifikan & 1466,72 \\
$(0,0,1)$ & Signifikan & 1465,42 \\
$(1,0,0)$ & Signifikan & 1464,76 \\
\hline
\end{tabular}

Dari ke-3 model yang telah peneliti uji, model-model yang signifikan dengan semua nilai koefisien < 0.05 adalah model 2 yaitu $\operatorname{ARIMA}(1,0,0)$, dan model 3 yaitu $\operatorname{ARIMA}(0,0,1)$, setelah itu peneliti akan menentukan model terbaik dengan melihat nilai AIC terkecil yaitu pada model (ARIMA $(1,0,0))$ yaitu 1464,76.

Setelah peneliti mendapatkan dua model yang signifikan yaitu $\operatorname{ARIMA}(1,0,0)$, dan $\operatorname{ARIMA}(0,0,1)$. Selanjutnya model tersebut peneliti lakukan uji autokorelasi untuk menentukan model mana yang cocok digunakan untuk meramalkan periode selanjutnya. 


\section{Ika Meiza Maharani ${ }^{1}$, Achmad Fauzan}
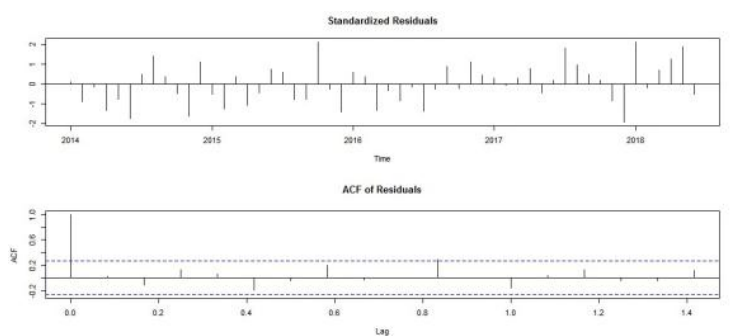

tor Ljung Box statistic

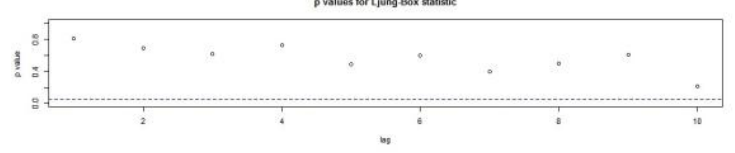

Gambar 4. Uji Diagnostik $(1,0,0)$
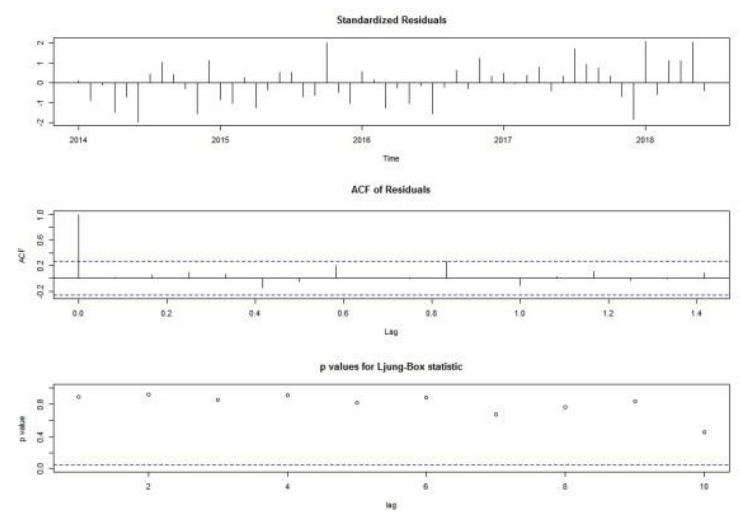

Gambar 5. Uji Diagnostik $(0,0,1)$

Dari hasil uji diagnostik pada gambar 4 dan 5 diatas dapat lihat bahwa residual model ARIMA $(1,0,0)$ dan ARIMA $(0,0,1)$ bersifat white noise yang ditandai dengan tidak adanya dua lag yang keluar dari batas interval. Selain itu pada grafik P-valuesfor L-jung Box statistic tidak terdapat titik-titik yang dibawah garis 0.05 yang menandakan hipotesis nol residual mengandung autokorelasi.

\section{Perbandingan Hasil Peramalan}

Perbandingan hasil peramalan Jumlah Produksi PKO di Mitra Mendawai Sejati-PKS Suayap tahun 2018.

Tabel 5. Perbandingan hasil peramalan

\begin{tabular}{lllll}
\hline Bulan & Actual & DMA & DES & ARMA \\
\hline Juli & 1053655 & 999543.6 & 822970 & 577239.5 \\
Agustus & 922239 & 1044376 & 831917.9 & 608607.1 \\
September & 915437 & 1089209 & 840865.8 & 608607.1 \\
Oktober & 743228 & 1134042 & 849813.7 & 608607.1 \\
November & 935261 & 1178874 & 858761.6 & 608607.1 \\
Desember & 955150 & 1223707 & 867709.5 & 608607.1 \\
Total & 5524970 & 6669751 & 5072038.5 & 3620275 \\
MSE & & $6.04644 \mathrm{E}+11$ & $3.41912 \mathrm{E}+10$ & $2.18421 \mathrm{E}+11$ \\
RMSE & & 777588.4776 & 184908.516 & 467354.8862 \\
MAPE & & $24.02 \%$ & $11,92 \%$ & $33,68 \%$ \\
\hline
\end{tabular}

Berdasarkan tabel dari perbandingan hasil peramalan dari metode Double Moving Average, Double Eksponential Smothing, dan ARMA dengan data asli dari produksi PKO PT di Mitra Mendawai Sejati-PKS Suayap tahun 2018 didapatkan nilai Mean Squared Error (MSE), Root Mean Square Error (RMSE) dan Mean Absolute Percentage Error (MAPE) terkecil yaitu terdapat pada metode Double Exponential Smothing, yaitu Mean Squared Error (MSE) sebesar 3.41912E+10, Mean Square Error (RMSE) sebesar 184908.516 dan Mean Absolute Percentage Error (MAPE) sebesar 11,92 \%, ketiganya merupakan metode untuk mengukur tingkat keakuratan suatu model peramalan, namun untuk lebih jelas dan sering digunakan biasanya menggunakan nilai MAPE karena dihitung dengan berdasarkan kesalahan dari tiap periode 


\section{Ika Meiza Maharani ${ }^{1}$, Achmad Fauzan}

kemudian dibagi dengan nilai obeservasi yang nyata untuk setiap periode tersebut, kemudian merata-rata kesalahan persentase absolut. Berdasarkan hal tersebut nilai MAPE lebih mudah digunakan karena berbentuk persentase.

\section{Peramalan untuk tahun 2019 dengan menggunakan metode terbaik}

Berdasarkan hasil perbandingan beberapa metode yang sudah digunakan, maka mendapatkan hasil bahwa metode Double Exponential Smothing ini yang terbaik untuk data PKO di PT. Mendawai Sejati-PKS Suayap.

Berikut hasil penentuan parameter optimum yang diperoleh melalui program $\mathrm{R}$ menggunakan metode Holt-Winter's Exponential Smoothing yang digunakan untuk meramalkan 6 periode kedepan yaitu tahun 2019

Tabel 6. Parameter Optimum

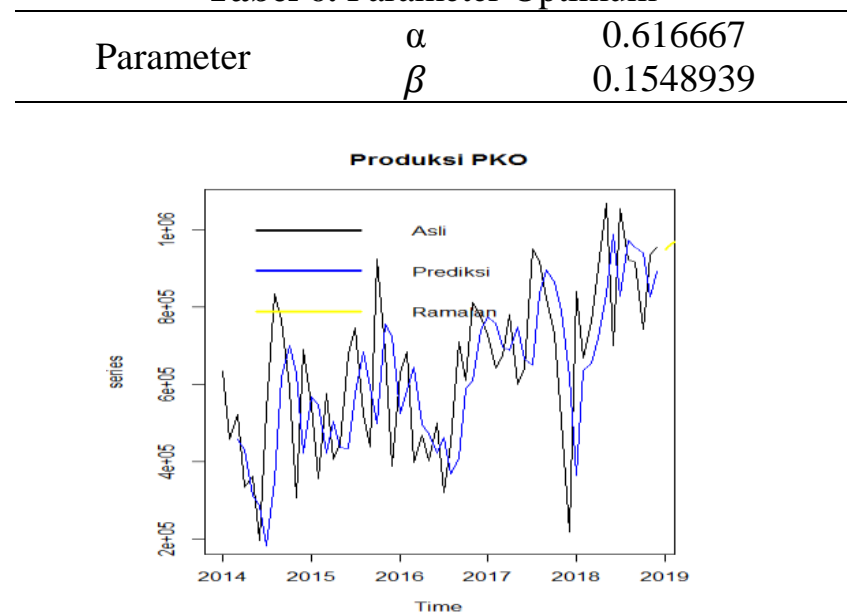

Gambar 6. Plot data Actual, Prediksi dan Peramalan

Berdasarkan gambar dihalaman sebelumnya, untuk visualisasi data aktual dan prediksi jumlah produksi PKO pada PT.Mendawai Sejati-PKS Suayap terlihat memiliki bahwa garis actual dengan prediksi hampir sama.

\section{Hasil Peramalan produksi PKO pada tahun 2019}

Untuk hasil peramalan produksi PKO pada PT . Mendawai Sejati-PKS Suayap tahun 2019 dapat dilihat gambar berikut :

Tabel 7. Hasil peramalan produksi PKO 2019

\begin{tabular}{ll}
\hline Bulan & Forecasting \\
\hline Januari & 949181.5 \\
Februari & 963505.8 \\
Maret & 977830.1 \\
April & 992154.4 \\
Mei & 1006478.6 \\
Juni & 1020802.9 \\
Total & 5909953.3 \\
\hline
\end{tabular}




\section{Ika Meiza Maharani ${ }^{1}$, Achmad Fauzan}

Berdasarkan gambar diatas diketahui bahwa jumlah produksi PKO di PT.Mendawai SejatiPKS Suayap tahun 2019 akan mengalami peningkatan dimana jumlah produksi paling banyak terjadi pada bulan Juni. Hasil peramalan jumlah produksi PKO di PT.Mendawai Sejati-PKS Suayap tahun 2019 yaitu sebesar $1020802.9 \mathrm{Kg}$.

\section{Nilai Kesalahan}

Selanjutnya dicari nilai error peramalan yang meliputi MES, RMSE, dan MAPE. Hasilnya sebagai berikut:

\begin{tabular}{lc}
\multicolumn{2}{c}{ Tabel 8. Nilai Error } \\
\hline MSE & 47031163817 \\
RMSE & 216866.7 \\
MAPE & 30.67187 \\
\hline
\end{tabular}

Dari hasil peramalan dengan menggunakan metode Holt-Winter's Exponential Smoothing diperoleh bahwa dengan menggunakan nilai parameter (pembobotan optimum) untuk $\alpha=$ 0.616667 dan $\beta=0.1548939$, maka didapatkan nilai MSE sebesar 47031163817, RMSE sebesar 216866 dan MAPE sebesar 30\%. MSE, RMSE dan MAPE merupakan metode untuk mengukur tingkat keakuratan suatu model peramalan. Jika semakin rendah tingkat kesalahan atau error maka keakuratan model semakin baik, namun sebaliknya jika tingkat error semakin besar maka keakuratan model semakin buruk. Dari hasil diatas penulis akan melihat dari nilai MAPE nya, $\mathrm{Ke} m$ a $\mathrm{m}$ u a $\mathrm{n}$ e $\mathrm{r}$ a $\mathrm{m}$ a $\mathrm{n}$ a $\mathrm{ng}$ a $\mathrm{b}$ a $\mathrm{ik}$ jika memiliki nilai M A P kurang dari $10 \%$ da $\mathrm{n}$ m e m p n y a ke ma m puan peramalan yang baik jika nilai M A P kurang dari $20 \%$. Berdasarkan hasil pada tabel 8 bahwa didapatkan nilai MAPE sebesar 30\% yang artinya bahwa kemampuan dalam meramalkan untuk produksi PKO tahun 2019 kurang baik karena lebih dari $20 \%$.

\section{Kesimpulan}

Berdasarkan pembahasan yang telah dipaparkan pada bab sebelumnya, maka dapat disimpulkan bahwa: Gambaran secara umum untuk jumlah Produksi PKO tertinggi yaitu pada tahun 2018 dengan jumlah Produksi PKO sebesar 10466134 kg dengan rata-rata produksi PKO setiap bulannya adalah 872177.8333 dan Growth sebesar $27448 \%$. Untuk perbandingan hasil peramalan dari metode Double Moving Average, Double Eksponential Smothing, dan ARMA dengan data asli dari produksi PKO PT di Mitra Mendawai Sejati-PKS Suayap tahun 2018 didapatkan nilai Mean Squared Error (MSE), Root Mean Square Error (RMSE) dan Mean Absolute Percentage Error (MAPE) terkecil yaitu terdapat pada metode Double Exponential Smothing. Berdasarkan output hasil peramalan diketahui bahwa jumlah produksi PKO di PT.Mendawai Sejati-PKS Suayap tahun 2019 akan mengalami peningkatan dimana jumlah produksi paling banyak terjadi pada bulan Juni. Hasil peramalan jumlah produksi PKO di PT.Mendawai Sejati-PKS Suayap tahun 2019 yaitu sebesar 1020802.9 Kg.

\section{Daftar Pustaka}




\section{Ika Meiza Maharani ${ }^{1}$, Achmad Fauzan}

[1] A. P. Sutiyono, "Outlook Industry Perkebunan 2009," 30 November 20092009. [Online]. Available: http://www.asiasecurities.co.id.

[2] W. S. M. Makridakis S., Metode dan Aplikasi Peramalan, Jakarta: Erlangga, 1999.

[3] P. Subagyo, Statistik Deskriptif, Yogyakarta: BPFE-Yogyakarta, 2003.

[4] Puspitaningrum, Moving Average (ARIMA) dan Exponential Smoothing, 2015.

[5] M. Firdaus, Analisis Deret Waktu Satu Ragam, Jakarta: IPB Press, 2006. 